\title{
Synchronous Endobronchial Carcinoid Tumor and Adenocarcinoma of the Lung: A Case Report and Review of the Literature
}

\author{
Nada Hajjaj ${ }^{1}$, Mohammad Abdulelah ${ }^{1}$, Nada M. Alsharif ${ }^{1}$, Elias Shamieh ${ }^{1}$, Husam Bader ${ }^{2}$ \\ 1. Department of Internal Medicine, University of Jordan, Amman, JOR 2. Department of Internal Medicine, \\ Presbyterian Medical Center, Albuquerque, USA
}

Corresponding author: Nada Hajjaj, nadahajjaj96@gmail.com

\begin{abstract}
Diagnosis of synchronous multiple primary lung cancers (SMPLCs) is a challenge as multiple lesions on chest $\mathrm{CT}$ imaging can be misdiagnosed as more common entities such as metastatic disease or infections. The possibility of multiple primary lung cancers should always be considered. Accurate diagnosis can significantly change the management and prognosis. We report a case of a 57-year-old woman, an exsmoker with chronic obstructive pulmonary disease (COPD), who was found to have synchronous endobronchial carcinoid tumor and adenocarcinoma of the lung. The association of carcinoid tumors and adenocarcinoma of the lung has been infrequently reported, with only a handful of cases published to date. Early diagnosis of resectable tumors can improve survival in patients with SMPLCs.
\end{abstract}

Review began 05/25/2021 Review ended 06/20/2021 Published 06/27/2021

\section{() Copyright 2021}

Hajjaj et al. This is an open access article distributed under the terms of the Creative Commons Attribution License CC-BY 4.0., which permits unrestricted use, distribution, and reproduction in any medium, provided the original author and source are credited.
Categories: Internal Medicine, Oncology, Pulmonology

Keywords: adenocarcinoma, carcinoid tumor, multiple lung tumors, synchronous lung tumors, metachronous lung tumors

\section{Introduction}

Lung cancer is the most common cause of cancer-related death for both sexes in the United States [1]. The differentiation between multiple primary lung tumors and metastatic lesions is of utmost importance as both management and prognosis can vary widely [2].

Multiple primary tumors can be synchronous or metachronous. Synchronous tumors are two or more tumors arising at the same time but with separate and distinct foci. The tumors may have similar or different histology [3]. Metachronous tumors are two or more tumors arising at different times in the same patient; most reported cases have different histology. If the tumors have similar histology, a two-year tumor-free period is required to diagnose metachronous tumor [4].

Among patients with lung cancer, the incidence of multiple primary lung tumors (both synchronous and metachronous) can vary from less than $1 \%$ to $16 \%$ [3]. Synchronous tumors are much less common than metachronous tumors, with an incidence of $0.5 \%$ to $2 \%$ in patients with lung cancer [5].

We report a case of a 57-year-old woman, an ex-smoker with chronic obstructive pulmonary disease (COPD), who was found to have synchronous endobronchial carcinoid tumor and adenocarcinoma.

\section{Case Presentation}

A 57-year-old female with mild COPD who presented to her primary care physician for fatigue and unintentional $40 \mathrm{lbs}$ weight loss over the past year. Initial work-up noted a possible right hilar mass for which the patient was referred to the pulmonary clinic.

The patient's known medical problems included mild COPD (per GOLD criteria for severity of airflow obstruction), well-controlled hypertension, hypothyroidism, obesity with BMI of 33, anxiety and a 15-20 pack-year smoking history. No pertinent family history of cancer. Upon interview, patient complained of a few weeks' worth of chills and night sweats. She denied fever, shortness of breath, chest pain or hemoptysis. No recent travel or known sick contacts. Physical examination revealed a well-nourished woman with no acute distress. Respiratory auscultation with bilateral air entry and no additional sounds. She exhibited no chest tenderness. Her complete blood count and complete metabolic panel were normal.

Initial chest radiograph revealed a possible right hilar mass. This was followed by a chest CT (Figure 1) which showed "a round 1.7 centimetre $(\mathrm{cm})$ pulmonary nodule in the right perihilar region containing internal macroscopic fat density with suspected airway occlusion". The nodule was suspected to either represent a pulmonary hamartoma or an endobronchial mass. Given the patient's weight loss and smoking history, the evaluation with bronchoscopy and biopsy was recommended. 


\section{Cureus}

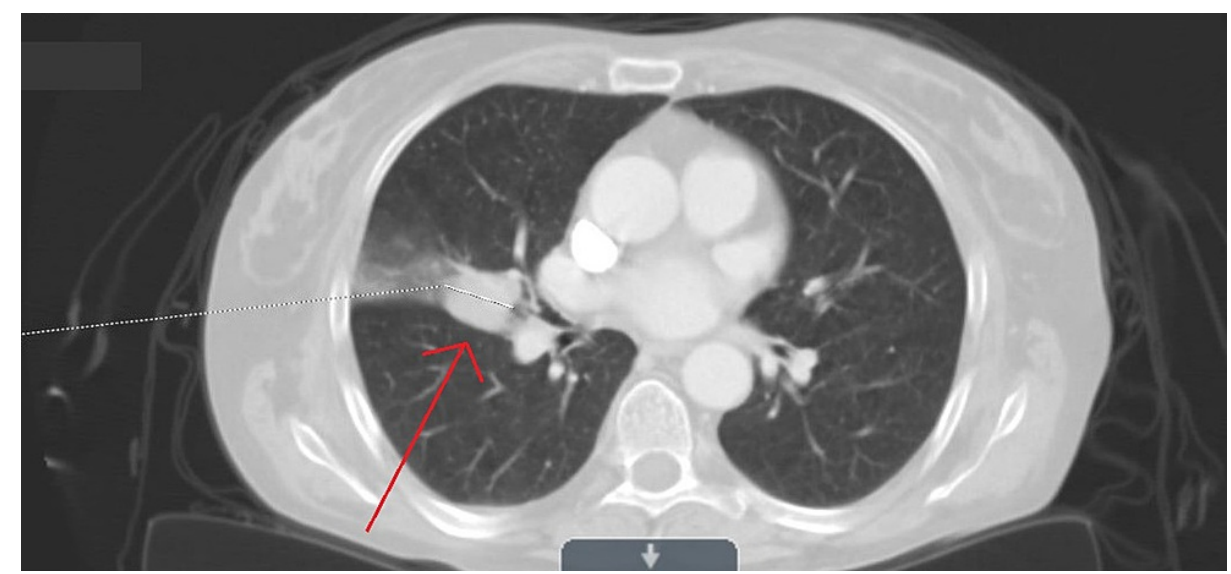

FIGURE 1: Chest CT showing a round $1.7 \mathrm{~cm}$ pulmonary nodule in the right perihilar region with adjunct ground-glass opacity.

CT: computed tomography.

Bronchoscopy revealed an endobronchial lesion in the lateral segment of the right middle lobe and 14 biopsies were taken. Pathology reported differentiated neuroendocrine (carcinoid) tumor, grade 1, mitotic rate of $<1 \%$, and Ki-67 fraction of $2.1 \%$ (Figure 2). Alveolar parenchyma showed no specific abnormality. Bronchoscopy was followed by an Octreotide scan which showed only minimal activity associated with the right mid lung nodule, indicating a somatostatin receptor-positive neuroendocrine tumor.

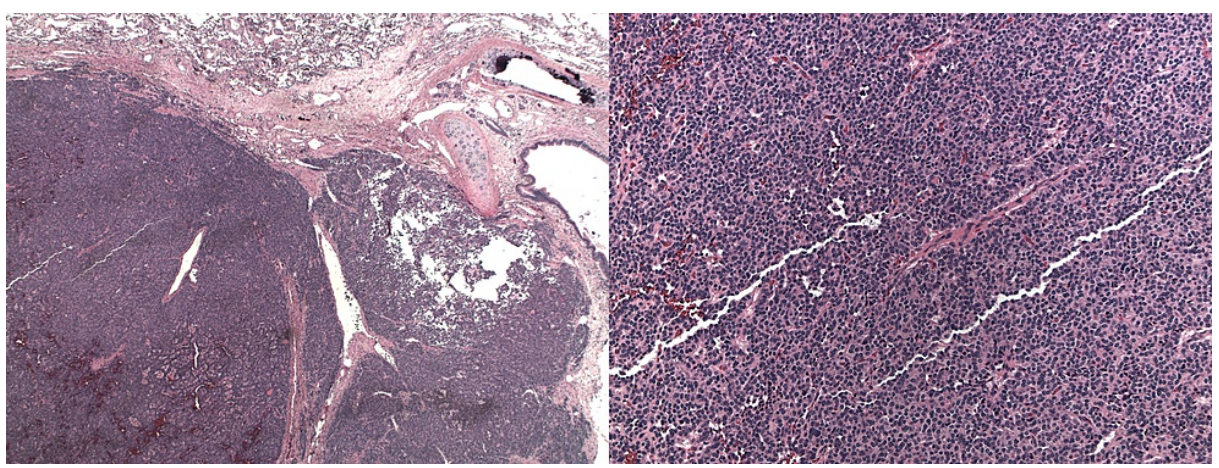

FIGURE 2: Biopsy results showing carcinoid tumor.

A positron emission tomography (PET) scan was done and noted a $0.87 \mathrm{~cm}$ hypermetabolic nodule in the right middle lobe. Given the timeframe of appearance of this nodule, differential diagnosis favoured postinflammatory changes or post-procedural reactive changes. There was no appreciated lymph node involvement on PET scan.

Subsequently, lobectomy was performed by the cardiothoracic surgeon. Post-operative pathology showed an unexpected two unrelated primary tumors; The previously diagnosed differentiated neuroendocrine tumor and a minimally invasive non-mucinous adenocarcinoma in the right middle lobe (Figure 3). Interestingly, both tumors were stage 1 without any lympho-vascular or adjacent structure invasion. Parenchymal margins were negative. 


\section{Cureus}

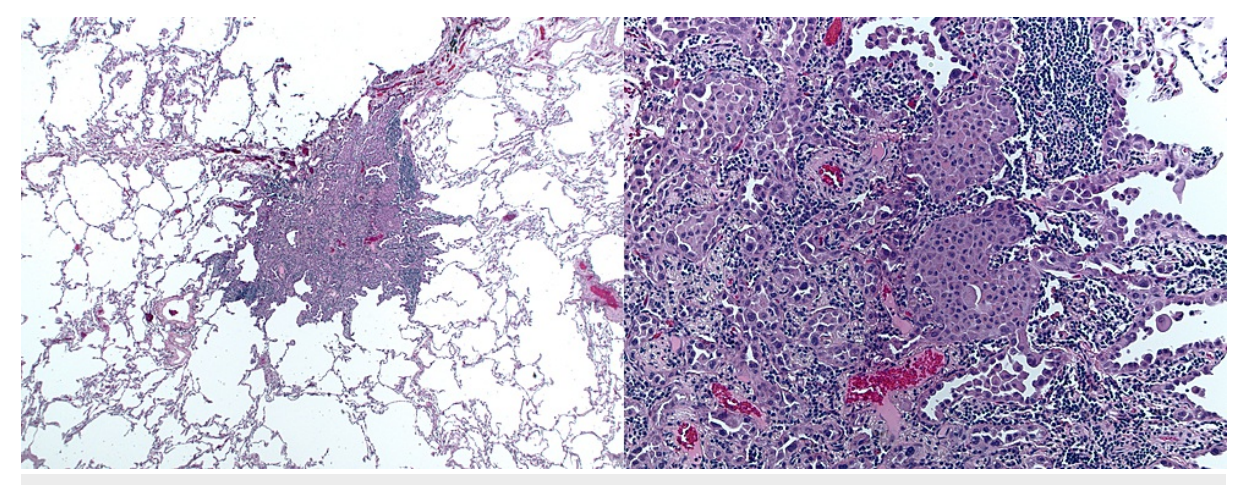

FIGURE 3: Pathology of the second mass showing adenocarcinoma of the lung.

Given the favorable staging and negative margins, lobectomy was felt to be therapeutic by the oncology team, and no adjuvant therapy was recommended. Surveillance protocol was done per National Comprehensive Cancer Network (NCCN) guidelines with CT chest every six months for the following two years. To date, patient remains disease-free with no evidence of recurrent malignancy in the lungs.

\section{Discussion}

Accurate staging of lung cancer is important for directing treatment and prognosis. A retrospective study at an academic center reviewed 83 patients who had undergone surgical resection of primary lung cancer with the intention of cure. Of these cancers, $20.5 \%$ had pathologically confirmed synchronous multiple primary lung cancers [6].

The scientific data addressing synchronous multiple primary lung cancers (SMPLCs) is not extensive. In 1924, Beyrenther first described them while doing post-mortem studies, the cancers he mentioned were small cell carcinoma along with adenocarcinoma of the lung [7]. Subsequently, few cases were reported describing synchronous squamous cell carcinoma with small cell carcinoma of the lung or synchronous squamous cell with squamous cell carcinoma [8].

Differentiation between synchronous and metachronous lung cancers is a challenging task. In 1975, Martini and Melamed proposed the need for two histologically distinct tumors to diagnose MSPLCs, except in cases where the tumor occurs in a different segment, lobe, or lung [9]. Subsequently, immunohistochemical staining $[5]$ and other factors were added to diagnose tumors with similar histology.

A retrospective analysis noted smoking to be an independent risk factor for the development of SMPLCs by inducing multifocal lung damage [10]. A phenomenon known as "field cancerization" is used when a certain carcinogen puts an entire field at risk of cancer [11]. Therefore, our patient's heavy smoking history (15-20 pack-year) may have contributed to the development of synchronous primary lung tumors.

There may be a misconception that the presence of multiple tumors indicates inevitable unresectability and is an indication for non-surgical first-line treatment. Synchronous primary tumors and primary lung tumors with intrapulmonary metastasis can be amenable for resection per the new recommendations of the 8th edition of the TNM classification of lung cancer [12]. In a metachronous lung tumor, the clinical stage of the second tumor determines if surgery is feasible or not, whereas, in synchronous lung tumors, each tumor should be staged and managed separately [13]. In our patient, due to favorable staging of both primary tumors, only surgical resection was done.

The association of lung adenocarcinoma and bronchial carcinoid is extremely rare with the first report published in 1966 by Roberts and Cumming [14]. Since 1966, only seven other cases were found describing synchronous endobronchial carcinoid and adenocarcinoma via a search conducted on PubMed, Google scholar, and Mednar using the keywords: "Synchronous", "lung", "adenocarcinoma" and "carcinoid" (Table 1). One study reported a case of triple synchronous lung cancer [15], and another study reported five synchronous tumors in one patient within seven years [16]. 


\section{Cureus}

\begin{tabular}{|c|c|c|c|c|c|c|}
\hline Case Report & Age & sex & $\begin{array}{l}\text { Smoking } \\
\text { history }\end{array}$ & $\begin{array}{l}\text { Stage at the } \\
\text { time of } \\
\text { diagnosis }\end{array}$ & Management & Follow up \\
\hline $\begin{array}{l}\text { Yano et al. (2002) } \\
\text { [17] (Original } \\
\text { article in } \\
\text { Japanese) }\end{array}$ & 58 & Female & - & - & $\begin{array}{l}\text { Right middle and lower } \\
\text { bilobectomy and mediastinal } \\
\text { lymph node dissection }\end{array}$ & - \\
\hline $\begin{array}{l}\text { Nagamstu et al. } \\
\text { (2012) [18] }\end{array}$ & 67 & Female & $\begin{array}{l}73.5 \\
\text { pack- } \\
\text { year } \\
\text { smoking } \\
\text { history }\end{array}$ & $\begin{array}{l}\text { Cancer-in- } \\
\text { cancer. Stage IA } \\
\text { (T1aNOM0) }\end{array}$ & $\begin{array}{l}\text { Right upper lobectomy with } \\
\text { mediastinal lymph node } \\
\text { dissection }\end{array}$ & - \\
\hline $\begin{array}{l}\text { Saladi et al. } \\
\text { (2018) [2] }\end{array}$ & 68 & Male & $\begin{array}{l}25 \text { pack- } \\
\text { year } \\
\text { smoking } \\
\text { history. }\end{array}$ & $\begin{array}{l}\text { Stage IV } \\
\text { adenocarcinoma } \\
\text { with pleural } \\
\text { metastasis }\end{array}$ & Palliative chemotherapy & - \\
\hline $\begin{array}{l}\text { Jung-Legg et al. } \\
\text { (1986) [15] }\end{array}$ & 49 & Male & $\begin{array}{l}60 \text { pack- } \\
\text { year } \\
\text { smoking } \\
\text { history. }\end{array}$ & - & $\begin{array}{l}\text { Right upper and middle } \\
\text { lobectomy, adjunctive } \\
\text { chemotherapy, and prophylactic } \\
\text { irradiation to the brain. }\end{array}$ & - \\
\hline $\begin{array}{l}\text { Flynn et al. (2004) } \\
\text { [16] }\end{array}$ & 63 & Male & $\begin{array}{l}\text { Previous } \\
\text { smoker. }\end{array}$ & - & $\begin{array}{l}\text { Right upper lobectomy (for latest } \\
\text { presentation with synchronous } \\
\text { triple tumors) }\end{array}$ & - \\
\hline $\begin{array}{l}\text { Mikhail et al. } \\
\text { (2020) [19] }\end{array}$ & 65 & Female & $\begin{array}{l}50 \text { pack- } \\
\text { year } \\
\text { smoking } \\
\text { history. }\end{array}$ & - & - & - \\
\hline $\begin{array}{l}\text { Sen and Borczuk } \\
\text { (1998) [20] }\end{array}$ & 60 & Female & $\begin{array}{l}45 \text { pack- } \\
\text { year } \\
\text { smoking } \\
\text { history. }\end{array}$ & $\begin{array}{l}\text { Stage II } \\
\text { adenocarcinoma }\end{array}$ & Left lower lobe lobectomy & $\begin{array}{l}\text { A follow-up chest (CT scan } 1 \\
\text { year later was negative for } \\
\text { recurrent tumor or } \\
\text { lymphadenopathy) }\end{array}$ \\
\hline
\end{tabular}

\section{TABLE 1: Case reports.}

Summary of seven published cases documenting synchronous lung tumors with pathology showing neuroendocrine and adenocarcinoma features. The databases included in the search were PubMed, Google scholar, and Mednar.

Four of the seven patients underwent surgical lobectomy with intent to treat, one underwent lobectomy with adjuvant chemotherapy and prophylactic radiation to the brain, one underwent palliative therapy due to advanced stage and the last had no described treatment plan. Follow-up was mentioned in only one of the seven cases where the patient had undergone lobectomy for stage II adenocarcinoma with synchronous neuroendocrine tumor. The patient remained in remission for the time of follow-up. The outcome mirrors that of the case we presented.

The median age of presentation was 63 years, with no gender predominance. The most striking feature between the cases published describing synchronous neuroendocrine and adenocarcinoma lung cancer was the extensive smoking history (median of 50 pack-year). This can be explained by the previously mentioned phenomenon of "field cancerization".

\section{Conclusions}

SMPLCs may present as multiple synchronous indeterminate lung nodules on chest CT. Diagnosis is challenging as this rare entity is often overlooked and excluded in the initial differential diagnoses in favor of more common etiologies. A high level of suspicion in patients with a smoking history coupled with accurate staging is essential. A multidisciplinary approach is of merit due to the rare and evolving nature of this entity. Lobectomy can be curative in the early stages.

\section{Additional Information}




\section{Disclosures}

Human subjects: Consent was obtained or waived by all participants in this study. Conflicts of interest: In compliance with the ICMJE uniform disclosure form, all authors declare the following: Payment/services info: All authors have declared that no financial support was received from any organization for the submitted work. Financial relationships: All authors have declared that they have no financial relationships at present or within the previous three years with any organizations that might have an interest in the submitted work. Other relationships: All authors have declared that there are no other relationships or activities that could appear to have influenced the submitted work.

\section{Acknowledgements}

Dr. Bader and I would like to thank Dr. Elizabeth Snyder for helping with the editing and sharing her insight and expertise.

\section{References}

1. American Cancer Society. Cancer Facts \& Figures . (2020). Accessed: May 15, 2021 : https://www.cancer.org/research/cancer-facts-statistics/all-cancer-facts-figures/cancer-facts-figures2021.html\#: :te....

2. Saladi L, Maddu SM, Niazi M, Matela A: Adenocarcinoma of lung and bronchial carcinoid presenting as double synchronous primary lung cancer: a case report and review of literature. World J Oncol. 2018, 9:1104. 10.14740/wjon 1129 w

3. Ferguson MK: Synchronous primary lung cancers . Chest. 1993, 103:398S-400S. 10.1378/chest.103.4_supplement.398s

4. Rzechonek A, Błasiak P, Muszczyńska-Bernhard B, et al.: Metachronous lung cancer: clinical characteristics and effects of surgical treatment. Adv Exp Med Biol. 2018, 1039:9-17. 10.1007/5584_2017_82

5. Copur MS, Lackner R, Wedel W, Lintel N, Lintel MS, Gnatra K: Synchronous bilateral lung cancer with discordant histology. Oncology. 2020, 34:55-60.

6. Smith NE, Harris ES, Gallant BP, Fabian T: Unexpected encounters: high prevalence of synchronous primary lung cancers in a tertiary academic center. J Thorac Dis. 2020, 12:2082-7. 10.21037/jtd-19-3990

7. Beyreuther H: Multiplicität von Carcinomen bei einem Fall von sog. "Schneeberger” Lungenkrebs mit tuberkulose. Virchows Arch. Path Anat. 1924, 250:230-43. 10.1007/BF01891568

8. Rohwedder JI, Weatherbee L: Multiple primary bronchogenic carcinoma with a review of the literature . Am Rev Respir Dis. 1974, 109:435-45. 10.1164/arrd.1974.109.4.435

9. Martini N, Melamed MR: Multiple primary lung cancers . J Thorac Cardiovasc Surg. 1975, 70:606-12. 10.1016/S0022-5223(19)40289-4

10. Guo H, Mao F, Zhang H, Qiu Y, Shen-Tu Y: Analysis on the prognostic and survival factors of synchronous multiple primary lung cancer. Zhongguo Fei Ai Za Zhi. 2017, 20:21-7. 10.3779/j.issn.1009-3419.2017.01.03

11. Gazdar AF, Minna JD: Multifocal lung cancers--clonality vs field cancerization and does it matter? . J Natl Cancer Inst. 2009, 101:541-3. 10.1093/jnci/djp059

12. Waller DA: Surgical management of lung cancer with multiple lesions: implication of the new recommendations of the 8th edition of the TNM classification for lung cancer. J Thorac Dis. 2018, 10:S268691. 10.21037/jtd.2018.04.159

13. Loukeri AA, Kampolis CF, Ntokou A, Tsoukalas G, Syrigos K: Metachronous and synchronous primary lung cancers: diagnostic aspects, surgical treatment, and prognosis. Clin Lung Cancer. 2015, 16:15-23. 10.1016/j.cllc.2014.07.001

14. Roberts GH, Cumming RL: A case report of two primary tumours: bronchial carcinoid and adenocarcinoma in the same lung. Br J Dis Chest. 1966, 60:160-3. 10.1016/s0007-0971(66)80036-0

15. Jung-Legg Y, McGowan SE, Sweeney KG, Zitzman JL, Pugatch RD: Synchronous triple malignant tumors of the lung. A case report of bronchial carcinoid, small cell carcinoma, and adenocarcinoma of the right lung. Am J Clin Pathol. 1986, 85:96-101. 10.1093/ajcp/85.1.96

16. Flynn MJ, Rassl D, El Shahira A, Higgins B, Barnard S: Metachronous and synchronous lung tumors: five malignant lung pathologies in 1 patient during 7 years. Ann Thorac Surg. 2004, 78:2154-55. 10.1016/S00034975(03)01514-5

17. Yano K, Yokoi K, Matsuguma H, et al.: Synchronous tumors consisted of bronchial carcinoid and adenocarcinoma of the lung . Kyobu Geka. 2002, 55:457-60.

18. Nagamatsu Y, Iwasaki Y, Omura H, Kumazoe H, Hyashida R, Shirouzu K: A case of resected synchronous multiple primary lung cancer comprising adenocarcinoma and carcinoid (cancer-in-cancer). Gen Thorac Cardiovasc Surg. 2012, 60:518-21. 10.1007/s11748-012-0029-z

19. Mikhail M, Narula N, Sharma D, Acharya S, Avula A, ElSayegh D: Concurrent lung adenocarcinoma and lung carcinoid tumor: a unique presentation of synchronous primary lung cancer. Am J Respir Crit Care Med. 2020, 201:5778. 10.1164/ajrccm-conference.2020.201.1_MeetingAbstracts.A5778

20. Sen F, Borczuk AC: Combined carcinoid tumor of the lung: a combination of carcinoid and adenocarcinoma . Lung Cancer. 1998, 21:53-8. 10.1016/s0169-5002(98)00042-7 